\title{
4. ASSESSMENT TYPOLOGIES USED WITHIN THE DISCIPLINE THEORY, SOLFEGGIO, MUSICAL DICTATION
}

\author{
Luminiţa Duţică ${ }^{40}$
}

\begin{abstract}
Assessment is a distinct stage within the teaching process, aiming to measure the level of the knowledge, skills and competences acquired within a given time frame. The discipline Theory, Solfeggio, Musical Dictation involves a synthesis between the theoretical and the practical side of the matter, and, as a result, it uses specific assessment tools for each side. Modern assessment methods involve personalized systems based on the diversification of types of docimological tests, quizzes, practical tests, etc. In this study we will present a series of personal contributions referring to the contents specific to the discipline Theory, Solfeggio, Musical Dictation taught at university.
\end{abstract}

Key words: assessment, music theory, solfeggio, dictation, tests

\section{Introduction}

With the desideratum of supporting the harmonious development of musician-trainees by balancing the two essential sides, i.e. the emotional and the rational, the discipline Theory, Solfeggio, Musical Dictation proves to be crucial in the training of young artists. It helps to form highly skilled musicians able to operate with complex musical languages, and at the same time it facilitates the deciphering, understanding, analysis, annotation and rendering of a score. Oriented conceptually by the General Theory of Music, solfeggio and dictation have always been basic tools in the teaching-learning-assessment process. They are complemented, ever since the level of specialized high school education, by questionnaires and quizzes in the Theory of Music, structured according to the contents taught. Within the teaching-learning process, assessment plays an extremely important role, leading to an increase in learning performance.

\section{Features of the process of didactic assessment}

With a view to develop quality education, current pedagogy aims to explore new assessment methods and processes in a consistent manner. Among the numerous researchers in the field of pedagogy, Louis Belair describes, in one of his books ${ }^{41}$, the current features of the concept of assessment:

- it is a means at the service of pupil or student progress;

- it stimulates student involvement;

- it ensures the objectivity and neutrality of the teacher's assessment;

- it develops self-esteem and helps to build a professional future.

Before the assessment process teachers need to ask themselves a series of questions about:

\footnotetext{
40 Professor PhD., „George Enescu” National University of Arts from Iaşi, Romania, email: luminitadutica@yahoo.com

${ }^{41}$ Louis Belair, L'évaluation dans l' école. Nouvelles pratiques, Paris, ESF, 1999
} 
- the expectancies targeted by student assessment;

- their role in informing, regulating and forming new skills abilities;

- the criteria and indicators that should be used;

- the type of global or sequential assessment;

- the assessment tools to be used;

- the moments of assessment: before, during, or after the action;

- their post-assessment decisions;

- the actions to be taken so as to improve the didactic process.

There are two types of problems: technical, referring to assessment forms/methods, and other problems, which determine the assessment direction, i.e. the start and end points of technical issues. Traditional assessment, based only on examination, should be replaced with ongoing (permanent) assessment activities, which should accompany every link in the chain represented by a seminar or course. Dan Ungureanu shows that "the modern meaning of the assessment strategy requires a perception as adequate and flexible as possible, owing to an assessment that is much more profound, complex, and, above all, dynamic /.../. Many other elements should be taken into account /.../, the need to offer to the assessor more freedom to move, to have initiatives, to be original and creative" ${ }^{42}$. Assessment types are classified according to three important criteria $^{43}$ :

1. the quantity of information: partial (everyday oral examination, written tests, practical tests) and global assessment (exams, contests);

2. the temporal axis of assessment: initial, ongoing and final;

3. the system of reference for value judgments: formative assessment (requirements taken from syllabi and course materials) and classifying assessment (system of reference represented by the performance of entire group or year of study)

4. the types of instruments used: objective assessment (tests, performance tests) and impressive assessments (based on the quality of results)

5. the object of assessment: summative assessment (based on learning outcomes) and formative assessment (stages leading to the end of an action)

6. the number of exponents involved: frontal (total), group, or individual assessment

7. the temporal axis: initial, ongoing (continual, formative) and final (summarizing) assessment

8. the assessment aims targeted: selection/hierarchy-oriented o recovery/develop ment-oriented assessment

\section{Methods of assessment}

In the field of education, the process of verifying whether goals have been met is carried out by combining several types of methods, techniques and tools, chosen carefully according to syllabus contents, the outcomes targeted and the

\footnotetext{
${ }^{42}$ Dan Ungureanu, Teroarea creionului roşu [Red Pen Terror], Timişoara, Ed. Universităţii de Vest, 2000, p. 15

${ }^{43}$ Apud Constantin Cucoş, Pedagogie [Pedagogy], second edition, Iaşi, Ed. Polirom, 2002, p. 378
} 
students' level of knowledge. As Michel Barlow shows, “designing, implementing and assessing the effects of a pedagogical undertaking are compulsory stages in a puzzle-like system: in order to understand its meaning one has to arrange its parts" 44 . Two main categories of methods are used in didactic assessment: traditional and modern. Paraphrasing Ioan Cerghit ${ }^{45}$, an important researcher and professor in the field, we could strengthen his ideas by saying that not all that is old is obsolete, and, likewise, not all that is new is valuable. Starting from these conclusions, choosing the types of methods used in the didactic process depends on each teacher's experience and creativity.

\subsection{Traditional assessment methods used in the discipline Theory, Solfeggio, Musical Dictation}

The traditional methods used with students in the seminars of Theory, Solfeggio, Musical Dictation adhere to the assessment types used in general pedagogy. Thus, oral assessment includes: exposition, recognition, demonstration, exemplification, exercise, explanation and analysis; theory-based assessment is carried out by exercises/activities, quizzes, analysis of musical texts, etc. Theoretical knowledge may be assayed especially through conversation, ideally heuristic, frontally, by group or individually, the students being asked all the time to discover the essence of the artistic phenomenon. Underlining the importance of oral assessment, Marin Manolescu said that "conversation has a great methodological flexibility which allows teachers to shape educational messages according to the actual conditions of instruction, and /.../ using language may sometimes shorten the road /.../ to the acquisition of what is new" ${ }^{46}$.

As to written evaluation, it is the main solution used in modern education, being applied successfully owing to the teachers' lack of subjectivity and the students' increased nervousness. In an extended time frame the latter are more likely to demonstrate the numerous new notions they have acquired throughout a semester or even an entire academic year. Written theoretical evaluation is a known form of assessing particular types of knowledge and skills acquired in the discipline of Theory, Solfeggio, Musical Dictation. It thus includes various types of compositional creativity tests, musical text analysis, questionnaires, etc.

These two forms of assessment are complemented by practical performance tests, which are crucial in the musical field; they aim to evaluate the ability to put into practice the theoretical knowledge, the skills and the abilities acquired. In fact, the bridge between "knowing" and "doing" should be a permanent focal point in every teacher's view. Referring to the discipline Theory, Solfeggio, Musical Dictation, a series of performance tests are crucial: solfeggio, musical hearing (melodic, harmonic, timbral), dictation (with all of its

\footnotetext{
${ }^{44}$ Michael Barlow, L'evaluation scolaire, Decoder son language, Chronique sociale, Lyon, 1992, p. 3

${ }^{45}$ Ioan Cerghit, L. Vlăsceanu (coord.), Curs de Pedagogie [Course in Pedagogy], Bucureşti, UB, 1988

${ }^{46}$ Marin Manolescu, Evaluarea şcolară - un contract pedagogic [School assessment - a pedagogical contract], Bucureşti, Ed. Fundaţiei Dimitrie Bolintineanu, p. 90
} 
types), rhythm/polyrhythm, musical improvisation, sound constructions (chordbased/sound aggregates, pitch classes, modes), musical compositions, etc.

\subsection{Modern assessment methods used in the course Theory, Solfeggio, Musical Dictation}

We have previously mentioned that traditional assessment methods are prevalent in our didactic activity, in the courses and seminars carried out with our students. They are complemented by the new assessment strategies involved in longer-term teaching activities, individual or group research, whose consequences are numerous skills, competences, and abilities. Also known under the name of complementary methods, they are represented by: systematic observation (assessment sheet, classification scale, control list), the investigation, the project, the portfolio and self-assessment. In the case of the investigation we may offer to the students various themes and bibliographic resources that could help them, in the future, to understand better the musical phenomena seen from within ever-changing sound processes. Examples:

- Describe the formation process of the Tonal-Functional Major-Minor System

- Evolution of modulation from the diatonic to the enharmonic stage during late Romanticism

During the research stage, the teacher plays only the role of an adviser to the student/group, allowing for total freedom of choice in the elaboration of a plan and specific conclusions. The project is an ampler, more creative investigation requiring more time to be completed. Individual or group research starts in class and continues at home through various methods of working. All the data are stored in electronic form, ordered by chapters and edited in a final form. The results are disseminated through a Ppoint presentation in front of one's classmates or of a bigger, but still informed, audience. The teacher assesses a sum of capabilities demonstrated by the students in their research: adequacy of working methods, techniques, and materials; correctness of analyses; accuracy of written material; creativity in approaching the topic; the manner in which the outcomes were presented orally.

A new, complex and integrating method of assessment used especially in the artistic field is the portfolio, an individual's "business card". It supposes the analysis, from one semester/year to the next, of all learning activities. The portfolio includes: oral, written, practical/performance tests, CDs/DVDs, projects, compositions, writings, prizes, diplomas, etc. By synthesizing a student's activities, the portfolio allows the teacher to draw objective conclusions about the student's progress, formed skills and abilities, accompanied by measures to remedy specific lacunae. Within the discipline Theory, Solfeggio, Musical Dictation, the portfolio is extremely useful as it contains the results of a wide array of personal activities, such as: dictations, brief personal compositions, analyses of classical scores, folk music collections, tests and questionnaires in the Theory of Music, CDs/DVDs with the student's own musical interpretations, interviews, individual or group rehearsals in order to study the art of musical interpretation, etc. 


\subsection{Digital assessment. The role of Wikis}

In musical practice numerous types of tests are used, referring to just one subject of study, or inter- and transdisciplinary topics. Computer-based working techniques are more and more frequent, requiring digital assessment methods. By means of Wikis (collections of Web pages) hosted by modern education platforms, which may be modified by those who are granted access, students may work together or with the help of their teachers on different online projects, in which they may gather and process in a coherent form unusual pieces of information found on various websites. They may be archived then researched through multiple connections between images, video projections, interviews, etc. The advantages are extraordinary, and collective work becomes much more exciting. The platforms similar to Wikispaces Classroom offer to teachers the possibility of generating projects choosing work teams, monitoring and assessing the students' research. Thus, the teacher may contact people living far away (musicologists, famous composers, folk music specialists, etc.), who otherwise would have never had the possibility of working with the team members in a traditional classroom. To sum up, modern assessment methods play an especially important role in enticing the study of music in a heuristic form in which the student, directed by the teacher, is able to actually investigate, discover, and understand the main phenomena pertaining to the very complex field of the musical art.

\section{The Test - the main method of assessment in the discipline Theory, Solfeggio, Musical Dictation}

An assessment tools with a very well-defined form is the test (oral, written, or practical). I.T. Radu ${ }^{47}$ highlights the role of this type of assessment and considers it the main means of obtaining relevant data on student performance. According to this scholar, the main features of the test are: easiness of operation, rapidity, accuracy in quantifying results, and objectivity of assessment. Assessment by grades or mentions is the product of three types of tests:

a. knowledge tests (based on various types of acquired knowledge)

b. pedagogical tests (conforming to established syllabi)

c. docimological tests (contest-like, in which case assessment takes into account several events)

\subsection{Types of tests and items}

A knowledge assessment test encompasses a set of questions or tasks named items, with strict assessment scales that may determine accurately the students' level of learning. The teacher should possess a sum of testing techniques able to make more efficient the evaluation of those under examination. As a matter of fact, the testing technique is the means through which the teacher "prompts and steers the production of answers from the

\footnotetext{
47 I.T. Radu, Evaluarea în procesul didactic [Assessment in the didactic process], Bucureşti, Ed. Didactică şi Pedagogică, 1999
} 
students, according to test objectives or specifications" ${ }^{48}$. There are numerous types of tests that may be personalized for the discipline Theory, Solfeggio, Musical Dictation ${ }^{49}$. Items:

1. Objective (closed-ended, based on memorization)

2. Semi-objective:

- prompting short answers

- fill-in the blanks

- structured questions

3. Subjective (open-ended, aiming to express the personality of the test-taker)

In what follows, we will provide some examples of items that could be used in the end-of-term examination of students in the discipline Theory, Solfeggio, Musical Dictation.

\section{Objective items}

- Classic items: List the intervals specific to the harmonic minor scale. What are the diatonic modes of Romanian folk music ?

- Multiple-choice item: Circle the terms referring to sound height

- Dual-choice item: Which of the two tetrachords are found in the melodic major scale?

- Matching item: Match the musical terms in the two diagrams

II. Semi-objective items

- Short-answer item (in the form of a question): What type of cadence is found in the musical fragment below?

- Fill in the blanks item:

$>$ text with lacunae: Mode ... has the augmented fourth and the minor seventh as its characteristic intervals.

text with gaps: The triad ... on step ... functions as a dominant only in ... and .... of the minor tonality.

- Structured-question item:

A material functioning as a stimulus (musical fragment) is presented and then there follow several sub-questions about the same example.

Example: To be analysed, a fragment from Book IV of the cycle Mikrokosmos by Béla Bartók. The composer's style is a product of the following language elements:

a. What mode specific to the composer is used?

b. What bar contains the golden section?

c. What type of bi-modalism is used?

d. Circle the $\boldsymbol{\alpha}$-chord.

III. Subjective items

- Problem solving item (a problem situation)

- Essay item

- Elaborate/developed answer item

\footnotetext{
${ }^{48}$ Marin Manolescu, op. cit., p. 128

${ }^{49}$ See the numerous examples in the volume Teoria muzicii prin teste şi chestionare [The Theory of music through tests and questionnaires] written by Luminiţa Duţică
} 
Subjective items require much more elaborate answers, in which we may observe the test-taker's imagination, logical memory, flexibility in writing, creativity, ability to synthesize various data, divergent thinking, capacity to generalize, etc.. For the discipline Theory, Solfeggio, Musical Dictation we may use subjective items especially for seminar homework assignments, partial assessments, or final exams. Here are some examples:

- Continue the given composition (melodic line) creating your own architecture within a number of 32 4/4 bars.

- Compose a melody that follows the following modulating trajectories.

- Conceive a musical piece for a solo voice according to the given form.

- After audition by score, present the most important aspects referring to the language techniques Musical syntaxes used.

- Compose a harmonic accompaniment adequate for the following melody line created for the piano.

- Transform these music themes according to the procedures discussed, creating four new rhythmic variations.

- Analyze the following musical fragment from Symphony No. 3, $1^{\text {st }}$ Mvt., by L.

v. Beethoven from the viewpoint of its harmonic structure. Describe 4 essential traits that define classical style.

- After audition by score (in which some bars were modified by the teacher), identify the deliberate errors within, correct them and analyze the fragment from the viewpoint of its intonation, rhythm, and harmony.

\section{Conclusions}

At the end of this incursion into the multitude of assessment methods and their various embodiments, we stress the need to establish a close relation between them, the contents, and the objectives of each lesson. As far as traditional or newer technologies are concerned, we believe it is essential to find a balance in their use, because it is the teacher who makes a method shine, making it efficient through the manner and the place where it is used. However, one should always remain connected to modern strategies in order to choose the best solution that may make the teaching-learning process more efficient.

\section{Bibliography}

1. Barlow, M. (1992). L'evaluation scolaire, Decoder son language, Lyon: Chronique sociale

2. Belair, L. (1999). L'évaluation dans l' école. Nouvelles pratiques, Paris: ESF

3. Cerghit, I. \& Vlăsceanu, L. (coord.) (1988), Curs de Pedagogie [Course in Pedagogy], Bucureşti: Ed. Universitară

4. Cucoş, C-tin. (2002). Pedagogie [Pedagogy], ediția a II-a, Iaşi: Ed. Polirom

5. Duţ̧ică, Gh. \& Duţică, L. (2004). Conceptul ritmic şi tehnica variaţională - o viziune asupra Barocului şi Clasicismului muzical [Rhythmic concept and variational technique. A view on Musical Baroque and Classicism], Iaşi: Editura Artes

6. Duţică, L. (2013). Teoria muzicii în teste şi chestionare [The Theory of music through tests and questionnaires], Iaşi: Ed. Artes 